\title{
Comparison of the Effects of Maropitant, Lidocaine, and Dextroketamine Administered by the Intratesticular Route in Dogs Undergoing Elective Orchiectomy
}

\author{
Lianna Ghisi Gomes', Nathalie Moro Bassil Dower', Matias Bassinello Stocco', \\ Andresa de Cássia Martini', Camila Calvi Menegassi Ferreira', Anderson Castro Soares de Oliveira², \\ Fabíola Niederauer Flôres ${ }^{3}$, Roberto Lopes de Souza ${ }^{4}$ \& Luciana Dambrósio Guimarães ${ }^{4}$
}

\begin{abstract}
Background: Balanced anesthesia achieved with combinations of inhaled and injectable drugs administered systemically or in loco-regional anesthetic blocks, is widely used in veterinary medicine. The use of anesthesia and/or local analgesia has already demonstrated benefits in the performance of elective orchiectomy in different species, there is no literature that evaluates the use of the maropitant intratesticular route. The present study evaluated the cardiorespiratory variables and analgesia produced by intratesticular blockade with maropitant, lidocaine, or dextroketamine during the trans-operative period along with the discharge and anesthetic recovery of dogs that underwent elective orchiectomy.

Materials, Methods \& Results: Used twenty-four dogs from routine elective orchiectomy, considered healthy based on the results of clinical and hematological tests. The animals were randomly divided into three groups and was applied intratesticularly $2 \%$ lidocaine at a dose of $1 \mathrm{mg} / \mathrm{kg}$ (GL), $5 \%$ dextrocetamina at a dose of $2.5 \mathrm{mg} / \mathrm{kg}$ (GC), or $1 \%$ maropitant at a dose of $1 \mathrm{mg} / \mathrm{kg}(\mathrm{GM})$. Anesthesia induction was performed with propofol (to effect), and stabilization of inhalational anesthesia was achieved with $1.7 \mathrm{~V} \%$ of sevoflurane diluted in $100 \%$ oxygen administered through a calibrated vaporizer and appropriate anesthetic system based on the animal's weight, being kept under spontaneous ventilation, After induction, we waited $10 \mathrm{~min}$ for stabilization of exhaled anesthetic concentration and then administered one of the treatments intratesticularly. After five min from the local block the surgical procedure was started during up to 15 min. Heart rate (HR), respiratory rate (RR), systolic arterial pressure (SAP), diastolic arterial pressure (DAP), mean arterial pressure (MAP), oxygen saturation of hemoglobin $\left(\mathrm{SatO}_{2}\right)$, end-tidal carbon dioxide partial pressure $\left(\mathrm{EtCO}_{2}\right)$, end-tidal sevoflurane concentration (EtSevo) in exhaled air, and body temperature $\left(\mathrm{T}^{\circ} \mathrm{C}\right)$ were measured before intratesticular administration of the agent and at specific time points during surgery, in addition to assessments of analgesia and evaluation of discharge and anesthetic recovery. Statistical analysis was performed using the Kolmogorov-Smirnov test $(P>0.10)$. The parameters $\mathrm{HR}, \mathrm{RR}$, SAP, DAP, MAP, T, EtCO ${ }_{2}$, and $\mathrm{SatO}_{2}$ were evaluated by analysis of variance (ANOVA), followed by the ScottKnott test (Software $\mathrm{R}^{\circledR}$ 3.2.0 - 2013), considering a significance level of $P<0.05$. The results did not show inter-drug differences for the evaluated variables.

Discussion: It was decided not to use premedication (MPA), so that we could accurately assess the analgesic effect of drugs, lidocaine, dextroketamine and maropitant, on intratesticular block during elective orchiectomy. In this study we demonstrated that these drugs promoted analgesia, because the trans-surgical values were relatively lower compared to baseline and within physiological limits for the species. In addition, it was noted that local analgesia used was efficient since even at the time of ligature and the incision spermatic cord which is described in the literature as the most painful part of the surgical procedure. The post-anesthetic recovery and discharge were quick in the absence of MPA, local analgesia without residual effects and the use of sevoflurane. The sevoflurane has a very low blood gas coefficient solubility, resulting in a recovery fast. Therefore, we can conclude that all of the drugs promoted analgesia and cardiorespiratory stability as well as rapid anesthetic recovery for elective orchiectomy in this species.
\end{abstract}

Keywords: local block, pain, analgesia, local analgesia.

DOI: $10.22456 / 1679-9216.92792$ 


\section{INTRODUCTION}

Balanced anesthesia is widely reported in Veterinary Medicine [37]. The use of intratesticular block has been conventionally employed for elective orchiectomy $[6,8,10,11,13,20,22,26,27,34]$, and can reduce the pain and nociceptive responses associated with castration $[8,13,20,26]$. Local anesthetics such as lidocaine have already shown proven benefits in intratesticular blocks or in the spermatic cord $[6,8,10,11,13,20,22,26,27,34]$; similarly, the ketamine and dextroketamine, promote effects similar to those of local anesthetics $[17,18,38-40]$ and are effective at dosages of 2.5 $\mathrm{mg} / \mathrm{kg}$ for intratesticular analgesia during elective orchiectomy in dogs [8].

Maropitant was developed and approved because of its predominantly central-acting antiemetic effect [29]. However, studies have shown that the antiemetic dose $(1 \mathrm{mg} / \mathrm{kg})$ administered by the subcutaneous (SC) route promoted a reduction in the minimum anesthetic concentration (MAC) of inhaled anesthetics in dogs and cats that underwent noxious surgical stimulation $[1,7,19,24,35]$. Maropitant is a neurokinin-1 (NK-1) receptor antagonist drug that is used in the treatment of visceral $[9,15,16,25,31,32]$ and somatic $[5,17,30]$ pain. Its peripheral effect has been demonstrated in an experimental study model, wherein it attenuated the effects of an NK-1 agonist (GR73632) [5].

Based on the hypothesis that maropitant presents analgesic efficacy, the present study aimed to evaluate and compare the cardiorespiratory variables and analgesia produced by an intratesticular block, in addition to evaluating discharge and anesthetic recovery in dogs that underwent elective orchiectomy and were anesthetized with sevoflurane.

\section{MATERIALS AND METHODS}

\section{Animals}

Twenty-four male dogs (mean weight, 9.95 $\pm 6.64 \mathrm{~kg}$; mean age, $2.80 \pm 1.93$ years) of different breeds, were selected from among the patients routinely admitted to the UFMT Veterinary Hospital and underwent elective orchiectomy. The animals were selected after clinical and laboratory examinations (complete blood count and urea, creatinine, alanine aminotransferase [ALT], and albumin measurements) and classified as ASA I according to the American Society of Anesthesiology (ASA).

\section{Experimental design}

After solid and liquid fasting for 12 and $3 \mathrm{~h}$, respectively, baseline variables were measured: heart rate (HR) was measured through auscultation with a stethoscope; respiratory rate (RR) was determined by assessing movements of the intercostal muscles; body temperature $\left(\mathrm{T}^{\circ} \mathrm{C}\right)$ was measured with a digital clinical thermometer ${ }^{1}$ via the rectal route; systolic arterial pressure (SAP), diastolic arterial pressure (DAP), and mean arterial pressure (MAP) were determined using the non-invasive oscillometric method petMAP ${ }^{\circledR 2}$ with the cuff on the thoracic limb, above the carpus, and covering $1 / 3$ of the diameter of the limb. Subsequently, catheterization was performed through the cephalic vein, and Ringer's Lactate ${ }^{3}(10 \mathrm{~mL} / \mathrm{kg} / \mathrm{h})$ and cephalothin ${ }^{4}(20 \mathrm{mg} / \mathrm{kg})$ were administered for antibiotic prophylaxis. The animals were administered propofol $^{5}$ (to effect) for induction, intubated with an orotracheal probe suitable for their weight, placed in a dorsal decubitus position under a thermal mattress to maintain body temperature, and maintained under general inhalation anesthesia with sevoflurane ${ }^{6}$ diluted in $100 \%$ oxygen and an anesthetic system adequate for the weight of the animal under spontaneous ventilation.

After $10 \mathrm{~min}$ to stabilize the expired concentration of sevoflurane ${ }^{6}$ at $1.7 \mathrm{~V} \%$, one of the following agents was administered via the intratesticular route: maropitant $^{7}(1 \mathrm{mg} / \mathrm{kg})(\mathrm{GM})$, lidocaine ${ }^{8}(1 \mathrm{mg} / \mathrm{kg})$ (GL), and dextroketamine ${ }^{6}(2.5 \mathrm{mg} / \mathrm{kg})(\mathrm{CG})$. The volume of the administered solution was divided into three parts, of which one-third was administered to each testicle and the remaining third was administered subcutaneously at the surgical site. After 5 min of the intratesticular application, the surgical procedure was initiated and lasted for $15 \mathrm{~min}$. At the end of the surgery, the vaporizer was switched off and meloxi$\mathrm{cam}^{9}(0.2 \mathrm{mg} / \mathrm{kg} / \mathrm{IV})$ was administered. If the animals presented sudden movements at the time of surgery, $\operatorname{propofol}^{5}(1 \mathrm{mg} / \mathrm{kg} / \mathrm{IV})$ as a rescue anesthetic was administered, and if they showed a $20 \%$ increase in SBP and HR compared with the baseline values, fentanyl ${ }^{6}$ $(1 \mu \mathrm{g} / \mathrm{kg} / \mathrm{IV})$ [23] was administered as a rescue analgesic. In order to reduce variations, the protocols used in each animal were unknown by the anesthesiologist, by the surgeon, and by the observer who assessed the discharge and anesthetic recovery. 


\section{Physiological variables}

The sensors of the multiparametric monitor ${ }^{10}$ were positioned as follows for measurement of cardiorespiratory variables during the transoperative period: Electrocardiogram electrodes ${ }^{11}$ were standardized in the thoracic and pelvic limbs for HR monitoring in small animals. The mainstream capnography sensor and anesthetic gas analyzer for the measurement of sevoflurane concentration (EtSevo), expired $\mathrm{CO}_{2}\left(\mathrm{EtCO}_{2}\right)$, and $\mathrm{RR}$ were attached at the end of the orotracheal tube. The pulse oximetry sensor was positioned on the tongue of the animal to measure oxygen saturation in hemoglobin $\left(\mathrm{SatO}_{2}\right)$. The esophageal thermometer was used to measure body temperature $\left(\mathrm{T}^{\circ} \mathrm{C}\right)$. SAP, DAP, and MAP were measured by the non-invasive oscillometric method petMAP ${ }^{\circledR 2}$, with the cuff on the thoracic limb above the carpus and covering $1 / 3$ of the diameter of the limb.

During anesthetic maintenance, the above variables were evaluated at baseline (M0), during intratesticular injection (M1), and at specific surgical time points: skin incision (M2), exteriorization of the first testis (M3), ligation of the pedicle of the first testis (M4), exteriorization of the second testis (M5), ligation of the pedicle of the second testis (M6), and beginning of the suture (M7).

\section{Anesthetic recovery}

Assessments for discharge and anesthesia recovery started soon after extubation and lasted until complete recovery, with evaluations being performed at 15-min intervals using the modified Aldrete and Kroulik scale, which assessed the following variables: motor activity, respiration, circulation, level of consciousness, and coloration of the mucosa. Grades from 0 to 2 were assigned for each variable according to the degree of functional recovery, with patients who obtained a score of at least 8 being eligible for discharge [3].

\section{Statistical analysis}

Statistical analysis was performed using the Kolmogorov-Smirnov test $(P>0.10)$. The parameters $\mathrm{HR}, \mathrm{RR}, \mathrm{SAP}, \mathrm{DAP}, \mathrm{MAP}, \mathrm{T}, \mathrm{EtCO}_{2}$, and $\mathrm{SatO}_{2}$ were evaluated by analysis of variance (ANOVA), followed by the Scott-Knott test (Software $\mathrm{R}^{\circledR} 3.2 .0$ - 2013), considering a significance level of $P<0.05$.

\section{RESULTS}

For the variables $\mathrm{HR}, \mathrm{RR}, \mathrm{DAP}, \mathrm{T}^{\circ} \mathrm{C}$, and $\mathrm{SatO}_{2}$, no statistically significant differences were observed between the groups, but the values for SAP, MAP, and $\mathrm{EtCO}_{2}$ showed significant differences between groups; in the GM group, the SAP at M2 and MAP at M4 were lower and the $\mathrm{EtCO}_{2}$ at $\mathrm{M} 1$ was higher than the corresponding values in the other groups evaluated (Table 1). Although the statistical significance of differences between the values obtained at different time points was not verified, the values evaluated during anesthesia maintenance were relatively lower than those obtained at baseline.

In the evaluation of discharge and anesthetic recovery, the mean duration of extubation \pm standard deviation was $1.62 \pm 0.74,1.62 \pm 1.06$, and $1.62 \pm 0.74$ min in the GM, GL, and GC groups, respectively. The values were similar between the groups and showed no significant intergroup differences. In addition, all the animals obtained the necessary note for discharged as soon as the first 15 min after extubation.

\section{DISCUSSION}

In order to ensure that only the effect of the local analgesic block was assessed during evaluations performed in the trans- and postoperative periods, application of the pre-anesthetic medication (MPA) was not performed. Additionally, a 15-min interval was added after induction with propofol, so that there was no influence of this drug during maintenance. This allowed stabilization of inhalational anesthesia and evaluation of sevoflurane and local blockade during the maintenance and post-anesthetic period, in contrast to other studies $[13,20,26]$ that used preemptive analgesia, which can interfere with subsequent evaluations.

The values of physiological variables, such as the dose-dependent cardiorespiratory depression and peripheral vasodilation, are known to decrease as a result of general anesthesia [21]; thus, it can be affirmed that the reduction in the variables observed in this study in relation to the baseline values is expected and irrelevant, since they remained within the acceptable limits for animals under general anesthesia.

Although the method used to measure blood pressure (BP) is not considered a "gold standard", it accurately identifies normotensive and hypertensive animals [33]. In this study, the variables were maintained within the accepted physiological levels for this species due to the low dose of anesthetic employed and the efficiency of the anesthetic block used, which produced adequate analgesia for the procedure, corroborating with the existing literature [21]. 
Table 1. Mean values and standard deviations of the physiological variables, namely, heart rate (HR), respiratory rate (RR), systolic arterial pressure (SAP), diastolic arterial pressure (DAP), mean arterial pressures (MAP), body temperature $\left(\mathrm{T}^{\circ} \mathrm{C}\right)$, partial pressure of carbon dioxide $\left(\mathrm{ETCO}_{2}\right)$, and oxygen saturation in hemoglobin $\left(\mathrm{SatO}_{2}\right)$, in dogs that were anesthetized with sevoflurane and subsequently received intratesticular administration of $1 \%$ maropitant citrate at a dose of $1 \mathrm{mg} / \mathrm{kg}(\mathrm{GM}), 2 \%$ lidocaine at a dose of $1 \mathrm{mg} / \mathrm{kg}(\mathrm{GL})$ and $5 \%$ dextroketamine at a dose of $2.5 \mathrm{mg} / \mathrm{kg}$ (GC) for elective orchiectomy.

\begin{tabular}{|c|c|c|c|c|c|c|c|c|c|c|}
\hline \multirow{2}{*}{ Variable } & \multirow{2}{*}{ Group } & \multirow{2}{*}{ Basal } & \multicolumn{8}{|c|}{ Moment } \\
\hline & & & M0 & M1 & M2 & M3 & M4 & M5 & M6 & M7 \\
\hline \multirow{3}{*}{ HR (bpm) } & $\mathrm{GC}$ & 134.25 & 113.38 & 122.88 & 120.50 & 120.00 & 119.00 & 114.38 & 115.25 & 113.62 \\
\hline & GL & 133.50 & 115.12 & 117.25 & 113.38 & 111.25 & 114.62 & 108.38 & 112.12 & 107.62 \\
\hline & GM & 134.75 & 119.38 & 119.62 & 114.00 & 116.38 & 118.00 & 116.12 & 113.75 & 114.38 \\
\hline \multirow{3}{*}{$\mathrm{RR}$ (mpm) } & GC & 35.25 & 11.88 & 15.62 & 16.50 & 12.88 & 12.50 & 12.25 & 11.50 & 12.25 \\
\hline & GL & 39.25 & 19.50 & 18.62 & 17.00 & 16.50 & 14.50 & 16.62 & 16.62 & 15.00 \\
\hline & GM & 36.75 & 20.12 & 16.50 & 13.00 & 12.38 & 12.25 & 10.12 & 12.38 & 11.88 \\
\hline \multirow{3}{*}{$\mathrm{SAP}(\mathrm{mmHg})$} & GC & 138.75 & 128.50 & 133.00 & $124.75 \mathrm{a}$ & 133.25 & 132.25 & 130.50 & 131.00 & 131.62 \\
\hline & GL & 151.12 & 135.62 & 131.88 & $135.12 \mathrm{a}$ & 132.50 & 130.75 & 133.62 & 135.62 & 130.88 \\
\hline & GM & 135.00 & 131.88 & 130.38 & $120.12 b$ & 125.25 & 127.50 & 129.50 & 129.62 & 132.62 \\
\hline \multirow{3}{*}{$\mathrm{DAP}(\mathrm{mmHg})$} & GC & 98.12 & 69.50 & 79.12 & 79.75 & 84.12 & 89.38 & 93.50 & 93.00 & 90.50 \\
\hline & GL & 97.88 & 76.25 & 78.75 & 84.00 & 80.38 & 82.25 & 81.50 & 82.62 & 85.38 \\
\hline & GM & 93.50 & 86.38 & 82.62 & 81.88 & 83.00 & 82.50 & 83.25 & 82.12 & 86.12 \\
\hline \multirow{3}{*}{ MAP $(\mathrm{mmHg})$} & GC & 120.50 & 91.00 & 103.62 & 101.88 & 106.62 & $107.62 \mathrm{a}$ & 105.62 & 111.75 & 112.25 \\
\hline & GL & 114.38 & 96.88 & 103.12 & 104.25 & 102.88 & $105.00 \mathrm{a}$ & 100.50 & 104.75 & 103.88 \\
\hline & GM & 120.38 & 100.12 & 99.88 & 92.00 & 96.12 & $92.00 \mathrm{~b}$ & 101.88 & 96.62 & 99.12 \\
\hline \multirow{3}{*}{$\mathrm{T}\left({ }^{\circ} \mathrm{C}\right)$} & GC & 38.62 & 38.26 & 38.11 & 38.09 & 38.02 & 37.99 & 37.95 & 37.92 & 37.86 \\
\hline & GL & 38.74 & 38.16 & 38.16 & 38.14 & 38.10 & 38.09 & 38.08 & 38.06 & 38.04 \\
\hline & GM & 38.55 & 38.33 & 38.16 & 38.11 & 38.04 & 38.00 & 37.94 & 37.92 & 37.94 \\
\hline \multirow{3}{*}{$\mathrm{ETCO}_{2}$} & GC & --- & 37.50 & $36.38 \mathrm{a}$ & 41.75 & 42.38 & 41.00 & 41.25 & 40.88 & 41.00 \\
\hline & GL & --- & 38.75 & $39.12 \mathrm{a}$ & 38.50 & 38.50 & 38.38 & 37.88 & 38.12 & 38.00 \\
\hline & GM & --- & 41.50 & $42.25 \mathrm{~b}$ & 40.62 & 40.88 & 40.25 & 41.12 & 40.62 & 40.75 \\
\hline \multirow{3}{*}{$\mathrm{SatO}_{2}(\%)$} & GC & --- & 99.88 & 99.62 & 99.75 & 99.75 & 99.75 & 99.75 & 99.75 & 99.75 \\
\hline & GL & --- & 99.75 & 99.75 & 99.75 & 99.38 & 99.75 & 99.75 & 99.75 & 99.38 \\
\hline & GM & --- & 99.75 & 99.62 & 99.62 & 99.38 & 99.50 & 99.50 & 99.50 & 99.38 \\
\hline
\end{tabular}

Mean values followed by the same letter do not differ from each other at a $5 \%$ level of significance.

Hypothermia, which can prolong the anesthetic recovery time [20], may also occur during anesthesia as a function of surgical time, drug action at the thermoregulatory center, reduction of metabolism, and responses to surgical stimuli, but these risks were reduced by maintenance with the use of a thermal mattress, allowing the temperature of the animals to be maintained between $37.5^{\circ} \mathrm{C}$ and $39^{\circ} \mathrm{C}$ [4].

The SatO2 and $\mathrm{EtCO} 2$ values were not evaluated at baseline due to the difficulty in evaluation since the animals were conscious, but all values remained within the allowable ranges during anesthetic maintenance, indicating that there was no respiratory depression.

All the variables evaluated were related to specific surgical times, since suture ligation and incision are described as the moments of greater nociception in this type of surgical procedure [36]. After the intratesticular block, an interval of 5 min was maintained before starting the surgical procedure to account for the latent period of the infiltrating drugs applied: lidocaine, 3-6 min [2]; ketamine or dextroketamine, 2 min [17]; and maropitant, less than 5 min [5].

In addition, the surgical time was standardized to $15 \mathrm{~min}$ to avoid extrapolating the time of action of the drugs in the testicles, since a previous study evaluating the permanence of intratesticular radioactive lidocaine in piglets observed enough analgesia for incision of the spermatic cord with a procedure time less than $20 \mathrm{~min}$ [28]. Therefore, surgical time was considered during elective orchiectomy so that the effect of the different drugs applied by this route can be used effectively, as reported by other authors [13]. 
There are few studies on the analgesic effects of maropitant, and there is no description in the literature of its use by the intratesticular route. However, its analgesic effect has been reported through other routes, e.g., when it was used intradermally in an experimental model with gerbil [5]. It has also been reported to show satisfactory analgesia for ovariectomy $(\mathrm{OH})$ with a single pre-operative dose of $1 \mathrm{mg} / \mathrm{kg}$ that was administered through the SC route in cats and dogs $[19,24]$, and showed analgesic potential similar to morphine [19]. Due to the lack of information on the ideal intratesticular dose, we decided to use the same dose as that used by the previously mentioned authors.

EtSevo was maintained at $1.7 \%$ based on a pilot study, which showed a decrease of approximately $27 \%$ of MAC for the species in question, being 2.36 $\pm 0.46 \mathrm{~V} \%$ [14]. This decrease could be attributed to the technique of balanced anesthesia, whereby the requirement of an inhalation anesthetic was reduced by an intratesticular block with lidocaine $[8,13,20]$ or dextroketamine [8]. The local analgesic effect of maropitant has been verified by confirmation of NK-1 receptors in the periphery $[5,12,30]$, which confirm its analgesic characteristics by promoting a reduction in CAM in dogs receiving nociceptive stimuli $[1,7,19,35]$.

The findings of this study affirm that there was adequate transoperative analgesia for the surgical procedure in all the groups, since none of the patients needed rescue anesthesia or analgesia despite the low concentrations of inhaled anesthetic used. Finally, rapid recovery may be justified by the absence of MPA, local analgesia without residual effects, and use of sevoflurane, which has a very low blood-gas solubility coefficient [14] that results in faster recovery. The results showed that in comparison with the use of lidocaine or dextroketamine, the application of maropitant by the intratesticular route is an analgesic technique that can be used effectively in dogs undergoing elective orchiectomy and can also promote high cardiorespiratory stability and rapid recovery of anesthesia.

\author{
MANUFACTURERS \\ ${ }^{1}$ Geratherm medical AG. Geschwenda, Germany. \\ ${ }^{2}$ Ramsey Medical Inc. and CardioCommand Inc. Tampa, FL, U.S.A. \\ ${ }^{3}$ Equiplex. Aparecida de Goiânia, GO, Brazil \\ ${ }^{4}$ ABL Antibióticos do Brasil. São Paulo, SP, Brazil. \\ ${ }^{5}$ Meizler Biopharma S.A. Barueri, Brazil. \\ ${ }^{6}$ Cristália - Produtos Químicos Farmacêuticos Ltda. São Paulo, SP, \\ Brazil. \\ ${ }^{7}$ Zoetis Inc. Parsippany, NJ, U.S.A. \\ ${ }^{8}$ Hipolar Farmacêutica Ltda. Belo Horizonte, MG, Brazil. \\ ${ }^{9}$ Ouro Fino. Cravinhos, SP, Brazil. \\ ${ }^{10}$ Shenzhen Mindray Bio-Medical Electronics Co. Ltd. Shenzhen, \\ China. \\ ${ }^{11}$ Tecnologia Eletrônica Brasileira Ltda. São Paulo, SP, Brazil.
}

Ethical approval. This study was approved by the Ethics Committee for Animal Use (CEUA) of the Federal University of Mato Grosso (UFMT) under protocol number 23108.232195/17-7, and consent was obtained from the owners of the patients.

Declaration of interest. The authors report no conflicts of interest. The authors alone are responsible for the content and writing of the paper.

\section{REFERENCES}

1 Boscan P., Monnet E., Mama K., Twedt D.C., Congdon J. \& Steffey E.P. 2011. Effect of maropitant, a NK-1 receptor antagonist, on anesthetic requirements during noxious visceral stimulation of the ovary in dogs. American Journal of Veterinary Research. 72(12): 1576-1579.

2 Calvey T.N. \& Williams N.E. 2008. Local anaesthetics. In: Principles and Practice of Pharmacology for Anaesthetists. 5th edn. Oxford: Blackwell Publishing, pp.149-170.

3 Cardoso A.R. 2001. Recuperação Pós-Anestésica. In: Yamashita A.M., Takaoka F., Auler Jr. J.O.C. \& Iwata N.I. (Eds). Anestesiologia. 5.ed. São Paulo: Atheneu, pp.1129-1141.

4 Cortopassi S.R.G. \& Fantoni D.T. 2010. Medicação pré-anestésica. In: Fantoni D.T. \& Cortopassi S.R.G. (Eds). Anestesia em Cães e Gatos. 2.ed. São Paulo: Roca, pp.217-227.

5 Costantini V.J.A., Corsi M., Dünstl G., Bettelini L., Zonzini L. \& Gerrard P. 2015. The NK1 receptor antagonist aprepitant attenuates NK1 agonist induced scratching behaviour in the gerbil after intra-dermal, topical or oral administration. Experimental Dermatology. 24(4): 296-319.

6 Dinniss A.S., Mellor D.J., Stafford K.J., Bruce R.A. \& Ward R.N. 1997. Acute cortisol responses of lambs to castration using a rubber ring and/or a castration clamp with or without local anaesthetic. New Zealand Veterinary Journal. 45(3): 114-121. 
7 Fukui S., Ooyama N., Tamura J., Umar M.A., Ishizuka T., Itami T., Iyoshi K., Sano T. \& Yamashita K. 2017. Interaction between maropitant and carprofen on sparing of the minimum alveolar concentration for blunting adrenergic response (MAC-BAR) of sevoflurane in dogs. The Journal of Veterinary Medical Science. 79(3): 502-508.

8 Gomes L.G., Travagin D.R.P., Peres-Cruz T.P.S., Spiller P.R., Winter D.C., Ens M.T.B., Dante L.C., Flôres F.N. \& Guimarães L.D. 2015. Influência da lidocaína ou da dexrocetamina pela via intratesticular na anestesia com sevoflurano em cães submetidos a orquiectomia eletiva. Acta Scientiae Veterinariae. 43: 1335.

9 Greenwood-Van M.B., Gibson M.S., Johnson A.C., Venkova K. \& Sutkowski-Markmann D. 2003. NK1 receptormediated mechanisms regulate colonic hypersensitivity in the guinea pig. Pharmacology, Biochemistry, and Behavior. 74(4): 1005-1013.

10 Haga H.A. \& Ranheim B. 2005. Castration of piglets: the analgesic effects of intratesticular and intrafunicular lidocaine injection. Veterinary Anaesthesia and Analgesia. 32(1): 1-9.

11 Haga H.A., Lykkjen S., Revold T. \& Ranheim B. 2006. Effect of intratesticular injection of lidocaine on cardiovascular responses to castration in isoflurane-anesthetized stallions. American Journal of Veterinary Research. 67(3): 403-408.

12 Hill R. 2000. NK1 (substance P) receptor antagonists - why are they not analgesic in humans? Trends in Pharmacological Sciences. 21(7): 244-246.

13 Huuskonen V., Hughes J.M.L., Bañon E.E. \& West E. 2013. Intratesticular lidocaine reduces the response to surgical castration in dogs. Veterinary Anaesthesia and Analgesia. 40(1): 74-82.

14 Kazama T. \& Ikeda K. 1988. Comparison of MAC and the rate of rise of alveolar concentration of sevoflurane, with halothane and isoflurane in the dog. Anesthesiology. 68(3): 435-437.

15 Laird J.M., Olivar T., Roza C., De Felipe C., Hunt S.P. \& Cervero F. 2000. Deficits in visceral pain and hyperalgesia of mice with a disruption of the tachykinin NK1 receptor gene. Neuroscience. 98(2): 345-352.

16 Laird J. 2001. Gut feelings about tachykinin NK1 receptor antagonists. Trends in Pharmacological Sciences. 22(4): 169.

17 López-Sanromán F.J., Cruz J.M., Santos M., Mazzini R., Tabanera A. \& Tendillo F.J. 2003. Evaluation of the local analgesic effect of ketamine in the palmar digital nerve block at the base of the proximal sesamoid (abaxialsesamoid block) in horses. American Journal of Veterinary Research. 64(4): 475-478.

18 López-Sanromán F.J., Cruz J.M., Santos M., Mazzini R., Tabanera A. \& Tendillo F.J. 2003. Effect of alkalinization on the local analgesic efficacy of ketamine in the abaxialsesamoid nerve block in horses. Journal of Veterinary Pharmacology and Therapeutics. 26(4): 265-269.

19 Marquez M., Boscan P., Weir H., Vogel P. \& Twedt D.C. 2015. Comparison of NK-1 Receptor Antagonist (Maropitant) to Morphine as a Pre-Anaesthetic Agent for Canine Ovariohysterectomy. PLoS ONE. 10(10): 1-10.

20 McMillan M.W., Seymour C.J. \& Brearley J.C. 2012. Effect of intratesticular lidocaine on isoflurane requirements in dogs undergoing routine castration. The Journal of Small Animal Practice. 53(7): 393-397.

21 Moldal E.R., Eriksen T., Kirpensteijn J., Nodtvedt A., Kristensen A.T., Sparta F.M. \& Haga H.A. 2013. Instratesticular and Subcutaneous lidocaine alters the intraoperative haemodynamic responses and heart rate variability in male cats undergoing castration. Veterinary Anaesthesia and Analgesia. 40(1): 63-73.

22 Molony V., Kent J.E., Hosie B.D. \& Graham M.J. 1997. Reduction in pain suffered by lambs at castration. The Veterinary Journal. 153(2): 205-213.

23 Natalini C.C., Cruz F.S.F. \& Bopp S. 2011. Analgesia epidural com clonidina ou sufentanil epidural em cadelas submetidas à ovariosalpingohisterectomia sob anestesia geral inalatória. Acta Scientiae Veterinariae. 39: 992.

24 Niyom S., Boscan P., Twedt D.C., Monnet E. \& Eickhoff J.C. 2013. Effect of maropitant, a neurokinin-1 receptor antagonist, on the minimum alveolar concentration of sevoflurane during stimulation of the ovarian ligament in cats. Veterinary Anaesthesia and Analgesia. 40(4): 425-431.

25 Okano S., Ikeura Y. \& Inatomi N. 2002. Effects of tachykinin NK1 receptor antagonists on the viscerosensory response caused by colorectal distention in rabbits. The Journal of Pharmacology and Experimental Therapeutics. 300(3): 925-931.

26 Perez T.E., Grubb T.L., Greene S.A., Meyer S., Valdez N., Bingman J. \& Farnsworth R. 2013. Effects of intratesticular injection of bupivacaine and epidural administration of morphine in dogsundergoing castration. Journal of the American Veterinary Medical Association. 242(5): 631-642.

27 Portier K.G., Jaillardon L., Leece E.A. \& Walsh C.M. 2009. Castration of horses under total intravenous anaesthesia: analgesic effects of lidocaine. Veterinary Anaesthesia and Analgesia. 36(2): 173-179. 
28 Ranheim B., Haga H.A. \& Ingebrigsen K. 2005. Distribuition of radioactive lidocaine injected into the testes in piglets. Journal of Veterinary Pharmacology and Therapeutics. 28(5): 481-483.

29 Ramsey D.S., Kincaid K., Watkins J.A., Boucher J.F., Conder G.A., Eagleson J.S. \& Clemence R.G. 2008. Safety and efficacy of injectable and oral maropitant, a selective neurokinin 1 receptor antagonist, in a randomized clinical trial for treatment of vomiting in dogs. Journal of Veterinary Pharmacology and Therapeutics. 31(6): 538-543.

30 Rost K., Fleischer F. \& Nieber K. 2006. Neurokinin 1 receptor antagonists - between hope and disappointment. Medizinische Monatsschrift für Pharmazeuten. 29(6): 200-205.

31 Ruggieri M.R., Filer-Maerten S., Hieble J.P. \& Hay D.W. 2000. Role of neurokinin receptors in the behavioral effect of intravesical antigen infusion in guinea pig bladder. The Journal of Urology. 164(1): 197-202.

32 Sakurada T., Katsumata K., Yogo H., Tan-No K., Sakurada S., Ohba M. \& Kisara K. 1995. The neurokinin-1 receptor antagonist, sendide, exhibits antinociceptive activity in the formalin test. Pain. 60(2): 175-180.

33 Seliskar A., Zrimsek P., Sredensek J. \& Petric A.D. 2013. Comparison of hight definition oscillometric and Doppler ultrasound with invasive blood pressure in anaesthetized dogs. Veterinary Anaesthesia and Analgesia. 40(1): 21-27.

34 Stafford K.J., Mellor D.J., Todd S.E., Gregory N.G., Bruce R.A. \& Ward R.N. 2002. Effects of local anaesthesia or local anaesthesia plus a non-steroidal anti-inflammatory drug on the acute cortisol response of calves to five different methods of castration. Research in Veterinary Science. 73(1): 61-70.

35 Swallow A., Rioja E., Elmer T. \& Dugdale A. 2017. The effect of maropitant on intraoperative isoflurane requirements and postoperative nausea and vomiting in dogs: a randomized clinical trial. Veterinary Anaesthesia and Analgesia. 44(4): 785-793.

36 Taylor A.A. \& Weary D. 2000. Vocal responses of piglets to castration: identifying procedural sources of pain. Applied Animal Behaviour Science. 70(1): 17-26.

37 Tonner P.H. 2005. Balanced anaesthesia today. Best Practice \& Research. Clinical Anaesthesiology. 19(3): 475-484.

38 Tverskoy M., Oren M., Vaskovich M., Dashkovsky I. \& Kissin I. 1996. Ketamine enhances local anesthetic and analgesic effects of bupivacaine by peripheral mechanism: a study in postoperative patients. Neuroscience Letters. 215(1): 5-8.

39 Ushida T., Tani T., Kanbara T., Zinchuk V.S., Kawasaki M. \& Yamamoto H. 2002. Analgesic effects of ketamine ointment in patients with complex regional pain syndrome type 1. Regional Anesthesia and Pain Medicine. 27(5): 524528.

40 Warncke T., Jorum E. \& Stubhaug A. 1997. Local Treatment with the N-methyl-d- aspartate receptor antagonist Ketamine, inhibit development of secondary hyperalgesia in man by a peripheral action. Neuroscience Letters. 227(1): $1-4$. 